\title{
McRae Trust - a study of issues around livestock greenhouse gas emissions and the implications for farmers
}

\author{
A.P. RHODES ${ }^{1}$, R.A. DYNES ${ }^{2}$ and M. BROWN \\ ${ }^{1} P G G$ Wrightson Consulting, $P O$ Box 42, Dannevirke \\ ${ }^{2}$ AgResearch, Lincoln Research Centre, PB 4749, Christchurch \\ ${ }^{3}$ AgResearch Grasslands, PB 11-008, Palmerston North \\ trhodes@pggwrightson.co.nz
}

\begin{abstract}
McRae Trust Farm was used to examine how hill country farming policies and management affected the quantity of livestock greenhouse gas (GHG) emissions, profitability, and risk. Land use decisions were subject to the opportunities and constraints inherent in the natural soil capital of the farm.

Analysis was undertaken using FARMAX ${ }^{\circledR}$ and OVERSEER $\AA$. Features of the pastoral farming system in 2009 were compared with 1990, and data around livestock GHG emissions was compared with the methodology proposed in the Climate Change (Agriculture Sector) Regulations 2010 which is intended to be the basis for calculating farmers' liability in 2015.

Changing livestock policies can potentially change livestock GHG emissions by around $10 \%$. Reduced emission intensity ( $\mathrm{kg} \mathrm{CO}-\mathrm{C} / \mathrm{kg}$ meat \& fibre) is achievable, but total GHG emissions may be increased over the baseline. Profitability, as measured by Economic Farm Surplus, may be increased or decreased with no relationship with the level of GHG emissions. Between 1990 and 2009, intensity of GHG emissions has been reduced by about $5 \%$ on this farm. An area of 12 ha of forestry will assist in reducing GHG liability in the initial period of agriculture's inclusion in the Emissions Trading Scheme (ETS).
\end{abstract}

\section{Introduction}

In 2008 the New Zealand Ministry of Agriculture and Forestry (MAF) implemented a plan of action intended to develop understanding around on-farm implications of greenhouse gas emissions and climate change. As part of this programme, case studies were undertaken on farms grazing sheep and beef cattle, deer and dairy stock across New Zealand. McRae Trust Farm, located at Frasertown, $8 \mathrm{~km}$ west of Wairoa, was chosen as one of the case-study farms, in part because the purpose of the farm is to provide benefit to the community through "promoting development, protection and education of exotic and indigenous flora and fauna" (McRae Trust 2011).

McRae Trust Farm comprises 612 ha of which 515 ha is estimated to be in pasture. Land contour is estimated to be $15 \%$ flat, $5 \%$ terraces, $30 \%$ easy hill,
$50 \%$ steep hill. Non-pastoral land use consists of 29 ha Pinus radiata, 16 ha Eucalyptus sp., 19 ha bush and arboretum and 55 ha manuka regeneration. Rainfall averages $1,450 \mathrm{~mm}$ annually, is variable, and summer/ autumn drought is experienced.

\section{Livestock Policy}

Livestock policies at McRae Trust have been developed to utilise the mix of land classes, soil structure and drainage characteristics, and pasture development across the farm, and provide a range of options to manage adverse climatic conditions that can be experienced. Animal numbers and performance reflect medium term trend c. 2009. No fertiliser nitrogen is routinely applied in the production system analysed, however nitrogen may be applied to assist recovery when adverse conditions are experienced.

Sheep policy: The farm runs a high performance breeding flock of 1,700 ewes docking $130 \%$ and retaining 620 replacements. The expectation is to finish a high proportion of the sale lambs off the farm by the end of April, although in dry seasons a number may be sold store.

Cattle policy: A beef breeding herd of 170 cows is run, breeding replacements, selling surplus heifers in May at 22 months and bulls in the spring at 26 months. This is complemented with 100 Friesian bulls, purchased in autumn at 7 months of age, and sold in October - December at 26-28 months of age.

In the 2009 season, production was $205 \mathrm{~kg}$ of carcass weight equivalents per hectare $(\mathrm{kg}$ of carcass weight plus $\mathrm{kg}$ of wool) (Table 1). (Meat \& fibre production is expressed as carcass weight equivalents. All sheep meat and beef production is converted to carcass weight units. Scoured wool weight is converted to carcass weight on a 1:1 basis).

Table 1 Production indices for McRae Trust Farm baseline c. 2009

\begin{tabular}{lc} 
Average sale lamb carcass weight (kg) & 17.2 \\
Meat \& fibre production (kg/ha) & 205 \\
Estimated annual feed demand (kg DM/ha) & 6031 \\
Stock unit equivalents (su/ha) & 10.9 \\
\hline
\end{tabular}




\begin{tabular}{|c|c|c|c|}
\hline & Methane $\left(\mathrm{CH}_{4}\right)$ & $\begin{array}{l}\text { Nitrous oxide } \\
\qquad\left(\mathrm{N}_{2} \mathrm{O}\right)\end{array}$ & $\begin{array}{l}\text { Combined } \\
\text { livestock GHG } \\
\text { emissions }\end{array}$ \\
\hline \multicolumn{4}{|l|}{ Whole-farm emissions from 515 ha } \\
\hline (tonnes $\mathrm{CO}_{2}$-e/year) & 1,385 & 561 & 1,946 \\
\hline \multicolumn{4}{|l|}{ Per hectare emissions } \\
\hline (tonnes $\mathrm{CO}_{2}$-e per ha/year) & 2.69 & 1.09 & 3.78 \\
\hline Emission intensity ( $\mathrm{kg} \mathrm{CO}_{2}$-e per $\mathrm{kg}$ of meat \& fibre) & 13.8 & 5.6 & 19.4 \\
\hline
\end{tabular}

\section{Greenhouse Gas Emissions}

Using the livestock policies and animal performance applying in 2009, the level and components of greenhouse gas (GHG) emissions resulting from livestock farming were estimated using OVERSEER $\AA$ ver. 5.4.8.0. to be equivalent to 1946 tonnes $\mathrm{CO}_{2}$-e per annum (Table 2).

For this analysis, only emissions directly associated with farming livestock have been considered. This accounts for methane from animals and nitrous oxide emissions from excreta and any applied nitrogen fertiliser. Carbon dioxide emissions due to fuel and energy consumption, lime application, nitrogen fertiliser manufacture and capital infrastructure are omitted, as under the New Zealand Emissions Trading Scheme (Climate Change Response (Emissions Trading) Amendment Act 2008), liability for these emissions will result at the time these goods and services are purchased. On this farm, carbon dioxide emissions are estimated to equate to only $2 \%$ of direct livestock emissions (41 tonnes/annum), a level typical in hill country farming systems.

\section{Mitigation of Livestock GHG Emissions}

Several options that may affect GHG emissions were examined:

1. increasing the sheep flock and decreasing cattle

2. assessing the impact of changes in animal production and productivity - comparing 1990 production with 2009 levels

3. application of a nitrification inhibitor

4. planting an area of hill country in forestry to provide dual timber and carbon credit benefits.

Livestock policies and the impact of changing livestock numbers and performance were assessed using FARMAX® ver. 6.3.71.3.

\section{Increasing sheep numbers and decreasing the beef herd}

The intent of this scenario was to assess the impact of a change in livestock policy that would result in an increase in the quantity of animal production for a similar level of dry matter production.

A high performance system was modelled in which the flock was increased to 3,140 ewes and the beef herd was replaced with a total of 205 bulls purchased in the autumn at 9 months of age. All bulls were sold by the end of April at approximately 20 months of age at an average $250 \mathrm{~kg}$ carcass weight.

The breeding cow herd was replaced by trading cattle as the herd was considered to have the highest total feed requirement per unit of production.

\section{Performance change since 1990}

Between 1990 and 2009 there was a significant change in the focus and level of performance achieved on sheep and beef farms. Over this period improvement in breeding ewe efficiency ( $\mathrm{kg}$ lamb weaned $/ \mathrm{kg}$ ewe mated live weight) has occurred, driven by a combination of flock reproduction genetics, improved nutrition and heavier ewe body weight. In addition, higher average lamb slaughter weight, and improved daily live weight gain in finishing cattle have also contributed to improvements in productivity in the sector.

Stock numbers, live weights and reproductive performance for McRae Trust Farm in the 1989/90 period were used to assess the nature of the impact of already adopted genetic improvement, improved livestock and feed management, and investment in pastoral production on both absolute and intensity indicators of livestock GHG emissions. In 1990, a flock of around 600 goats was also farmed for fibre. Production and methane emissions from these have been estimated in this analysis.

\section{Nitrification inhibitor}

Nitrous oxide currently comprises $28 \%$ of the greenhouse gas emissions from livestock on this farm, attributable to dung and urine deposition and breakdown.

Nitrification inhibitor is applied to the soil and acts to slow down the conversion of ammonium to nitrate. This has the potential to reduce both nitrate leaching and nitrous oxide losses, principally through the AprilAugust period. Although not commonly used on extensive hill country systems, a possible role would be to apply nitrification inhibitor to the 104 ha of land most intensively grazed by cattle through winter. On this farm, high rainfall and warm winter soil temperatures are likely to reduce the effectiveness of an inhibitor. 
Table 3 Effect of scenario on farm livestock emissions, emissions intensity and farm profitability

\begin{tabular}{lccccc}
\hline Scenario & $\begin{array}{c}\text { Whole-farm } \\
\text { livestock } \\
\text { emissions } \\
\text { (tonnes } \mathrm{CO}_{2} \text {-e) }\end{array}$ & $\begin{array}{c}\text { Per hectare } \\
\text { emissions } \\
\text { (tonnes } \mathrm{CO}_{2} \text {-e } \\
\text { per ha) }\end{array}$ & $\begin{array}{c}\text { Farm production } \\
\text { (kg of meat \& } \\
\text { fibre per hectare) }\end{array}$ & $\begin{array}{c}\text { Emission } \\
\text { intensity (kg } \\
\mathrm{CO}_{2} \text {-e per kg of } \\
\text { meat \& fibre) }\end{array}$ & $\begin{array}{c}\text { Farm profitability } \\
\text { (Economic farm } \\
\text { surplus) }\end{array}$ \\
\hline Baseline & 1,946 & 3.78 & 195 & 19.4 & $\$ 65,348$ \\
Incr. ewe and finishing cattle & 2,198 & 4.27 & 242 & 17.6 & $\$ 144,485$ \\
1990 performance & 1,711 & 3.33 & 163 & 20.3 & $-\$ 5,450$ \\
Nitrification inhibitor & 1,890 & 3.67 & 195 & 18.9 & $\$ 44,548$ \\
\hline
\end{tabular}

\section{GHG Emissions}

The impact of various scenarios on the level and intensity of emissions have been compared with the baseline scenario (Table 3 ).

Increasing sheep numbers and decreasing cattle was reflected by an increase in annual animal production and productivity from 195 to $242 \mathrm{~kg}$ meat and fibre/ha, and a significant change in the stock unit ratio of sheep to cattle, from $51: 49$ to $81: 19$.

This scenario was estimated to increase total farm livestock GHG emissions by $13 \%$, a total of 252 tonnes $\mathrm{CO}_{2}$-e. However, with an increase in the level of saleable meat and fibre production, intensity of emissions was reduced by $10 \%$, from 19.4 to $17.6 \mathrm{~kg}$ $\mathrm{CO}_{2}$-e per kg meat and fibre (carcass weight equivalent).

In short, changing the cattle policy away from a breeding-herd based system, where each cow weans 0.4 $\mathrm{kg}$ live weight of calf per $\mathrm{kg}$ of cow mated live weight, and increasing sheep numbers, where each ewe weans $0.6 \mathrm{~kg}$ live weight of lamb per $\mathrm{kg}$ of ewe mated live weight, results in higher productivity. With this change in policy, more of the feed grown is utilised, and a greater proportion of the feed consumed would be used for meat production compared to maintenance feeding.

Correspondingly, farm profitability as indicated by the Economic Farm Surplus is expected to increase to $\$ 144,485$ under this scenario. The Economic Farm Surplus (or earnings before interest and tax) is calculated as follows: net cash income plus change in livestock values less farm working expenses less depreciation less wages of management.

Gains in animal performance and productivity since 1990 are likely to have resulted in an increase in total farm livestock GHG emissions of 235 tonnes $\mathrm{CO}_{2}$-e. However, current annual animal production is $20 \%$ greater than the 1990 level of $163 \mathrm{~kg} / \mathrm{ha}$. Consequently, although total livestock emissions have increased 14\% over the period, intensity of emissions decreased $5 \%$, from $20.3 \mathrm{~kg} \mathrm{CO}$-e per $\mathrm{kg}$ meat and fibre (carcass weight equivalent) to $19.4 \mathrm{~kg} \mathrm{CO}_{2}$-e per $\mathrm{kg}$ meat and fibre.

The main factors that have driven this increase in productivity since 1990 are an increase in average flock weaning performance, from $85 \%$ to $135 \%$, while maintaining constant lamb weaning weight, and faster weight gain in finishing cattle, enabling heavier sale weight at the same age. This improvement has been enabled through increased pasture production, greater emphasis on per head animal performance and heavier ewes at mating, improved flock reproductive genetics, and improved feed utilisation, and is typical if the gains that have been made on many North Island hill country farms through this period.

Nitrification inhibitor applied in April and July to 104 ha of cattle grazing land is estimated to reduce nitrous oxide emissions from 562 to 508 tonnes $\mathrm{CO}_{2}-\mathrm{e}$ equivalent, a 54 tonne reduction. Overall nitrification inhibitor use was predicted to reduce whole-farm emissions by $3 \%$, but this was not economically feasible. At an applied cost of $\$ 20,800$ ( $\$ 100$ per application (Ravensdown 2009)) this reduction in emissions is achieved at a very high cost of $\$ 392$ per tonne of $\mathrm{CO}_{2}$-e equivalent.

\section{Emissions Trading Scheme Liability}

The New Zealand Emissions Trading Scheme (ETS) (Climate Change Response (Emissions Trading) Amendment Act 2008) puts a price on the emission of GHGs and is intended to provide incentives to encourage sectors to lower their emissions. It recognises emissions removed from the atmosphere through carbon forestry sequestration activities. It also establishes 1 January 2015 as the date on which agriculture joins the ETS. The primary unit of trade in the ETS is the New Zealand Unit (NZU). One NZU represents one tonne of carbon dioxide equivalent emissions $\left(\mathrm{CO}_{2}\right.$-e) either released to the atmosphere (emissions) or removed from the atmosphere (removals). As agriculture is a trade exposed industry, the legislation provides in 2015 for an initial free allocation of units equivalent to $90 \%$ of a yet to be determined level of emissions.

Additionally, the Climate Change (Agriculture Sector) Regulations 2010 establish the methodology by which liability for emissions from agriculture will be assessed when animal products are processed. The liability the sheep and beef farmer will face for emissions from livestock farming will be assessed based on emission factors for the number and carcass weight of animals processed through the meat industry. 


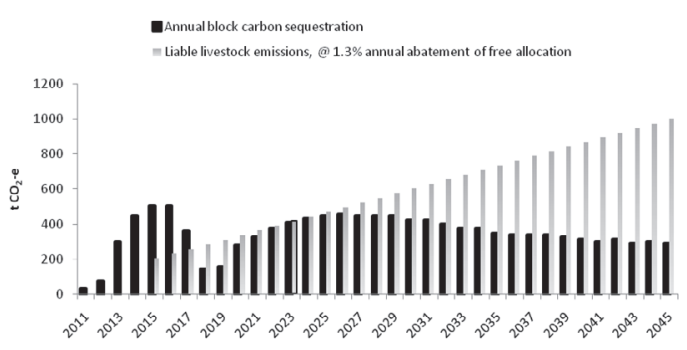

Figure 1 Annual liable livestock emission and annual carbon sequestration from a 12 ha block of aforestation

Applying these emission factors to the 2009 base-line production on McRae Trust Farm, the assessed level of whole-farm livestock emissions is 2,043 tonnes $\mathrm{CO}_{2}$-e. This is similar to the OVERSEER $\AA$ derived estimate of 1,946 tonnes $\mathrm{CO}_{2}$-e.

As the basis for the $90 \%$ free allocation of units is yet to be determined, it has been assumed that liability for livestock greenhouse gas emissions in 2015 will amount to $10 \%$ of total farm emissions or $204 \mathrm{NZU}$, which, at $\$ 20$ per unit, will amount to $\$ 4,086$.

\section{Sequestration and Management of Risk around ETS Liability}

Forestry and aforestation are important features of the McRae Trust Farm, and have been integrated into the landscape driven by a mix of aesthetic, land stabilisation and preservation of indigenous flora and fauna objectives.

There is scope for additional aforestation to complement these objectives, and concurrently add an additional revenue stream from sequestration of carbon. Importantly, carbon sequestration, through aforestation, also offers potential to manage the exposure of the pastoral farming enterprise to the liability for livestock emissions.

Livestock farming faces two risks around liability for livestock greenhouse gas emissions under the New Zealand ETS: legislation currently prescribes that the level of free allocation of units abates at the rate of $1.3 \%$ per annum from the $90 \%$ allocation in 2015 ; and the cost of NZUs that need to be purchased to meet the liability will be subject to market forces.

Engaging in a programme of carbon sequestration through aforestation can enable liability for livestock emissions to be aligned and a natural hedge to be established, independent of variability in the market price for NZUs.

One option is to plant an additional 12 ha of steeper hill land in Pinus radiata managed to 450 stems per hectare for clearwood and carbon credits. This scenario was one of 13 forestry options assessed in a site-specific study undertaken on this property (West et al. 2008).

The annual rate of carbon sequestration is based

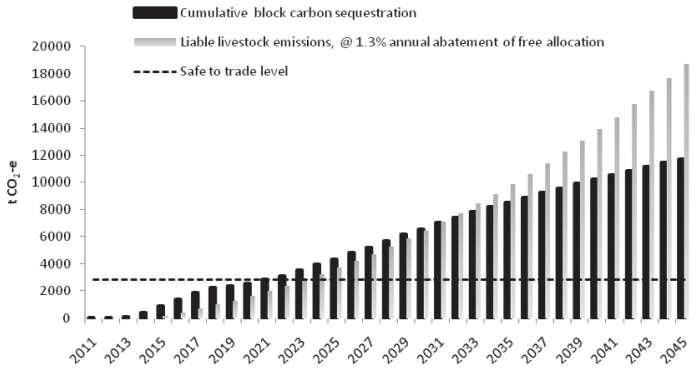

Figure 2 Cumulative liable livestock emissions and cumulative carbon sequestration from aforestation

on data for Wairoa district published in look-up tables (MAF 2011). These look-up tables provide the mandatory data that forest owners must use when calculating the amount of carbon stored in forests of less than 100 ha that are registered in the ETS. The carbon sequestered annually by 12 ha of forest planted in 2011 would match or exceed the increasing annual liability for livestock emissions until at least 2023 (Fig.1).

Although liable livestock emissions are forecast to increase steadily as a result of annual abatement of the free allocation of units, annual carbon sequestration can be more variable due to pruning and thinning practices. However, any surplus between sequestration and liability can be "stored" and used to meet future liabilities. In this way, the 12 ha forest planting undertaken in 2011 would be able to offset total liable livestock emissions through to 2032 (Fig. 2).

However there is a caution. When the forest is logged, liability for emissions is incurred, equivalent to the difference between the NZUs claimed for carbon stock in the forest and the minimum residual postharvest carbon stock in the period following harvesting and forest re-establishment.

For this forest, the minimum residual post-harvest carbon stock in the period following harvesting and forest re-establishment is calculated using look-up tables to be 233 tonnes $\mathrm{CO}_{2}$ per hectare. This quantity represents the "safe to trade" amount of sequestered carbon that can be claimed and sold, without incurring liability to repay NZUs when the forest is logged.

The total amount of carbon sequestered between 2011 and 2032 would amount to 7400 tonnes (617 tonnes $\mathrm{CO}_{2} /$ ha). If all these NZUs were sold to meet liability for livestock emissions, following harvest the forest owner will be obligated to purchase and surrender 4600 NZUs (617 tonnes/ha less 233 tonnes/ha). This introduces speculative risk as units are inevitably sold and purchased through different periods of time at which the value of NZUs can be expected to fluctuate in response to market forces.

By selling carbon sequestered beyond 2023 to offset liabilities, the "safe to trade threshold" for the forest 
would be exceeded. One option to manage this risk would involve planting an additional 12 ha of forest in 2022 , creating a new source of carbon sequestration to off-set liable annual livestock emissions.

\section{Conclusions}

Hill country sheep and beef farmers have a very limited range of options by which they can influence the level of livestock GHG emissions from their business. The extent of the change in livestock emissions that can be achieved is generally limited to around plus or minus $10 \%$.

In considering GHG emission changes it is necessary to identify the outcome that is desired. Changing livestock policies in a way that increases the amount of animal production in preference to maintenance feeding of stock may reduce the intensity of greenhouse gas emissions. However, at the same time, total farm livestock emissions may actually increase, depending on the feed supply and demand balance and change in feed utilisation. There is evidence that the sheep and beef sector has, since 1990, successfully reduced the intensity of GHG emissions associated with producing each tonne of meat and fibre by the order of $10 \%$.

However, in evaluating land use and livestock policies, management of GHG emissions and liability for these is only one of a range of factors farmers are likely to consider. Land capability, climate, forage supply, animal performance, and personal preference, when interwoven with market outlook, infrastructure capacity and attitude to risk, are likely be more dominant influencers of farmer behaviour than is GHG emission liability. This situation can be expected to continue, at least for the next decade, so long as the cost of NZUs remains in the range of $\$ 20-\$ 30 / \mathrm{NZU}$.

The three approaches to management of the cost and risk of liability for livestock GHG emissions explored in this case study indicate the challenges hill country livestock farmers, and the nation, face. Changing livestock policies can influence the intensity of emissions per unit of output, albeit the impact is modest and of the order of $10 \%$. However, where there is an economic imperative to change it is rational to expect farm business profitability and financial risk to be key drivers. GHG emissions liability, and the extent to which this liability can be managed, is unlikely to influence behaviour. Through acting to improve the efficiency of use of resources, farmers can reduce the intensity of GHG emissions per unit of output, however there is likely to be an increase on total farm emissions, which has implications for the nation. Investing in nitrification inhibitor technology to reduce GHG emissions is currently unviable in hill country, even where use is limited to the most intensive cattle-grazing area of the farm.
Management of risk, resulting from escalation in the price of carbon, through implementing an aforestation programme is an option available to many North Island hill country farmers. Planting 12 ha of forest on a 514 ha property would enable full liability for livestock emissions to be hedged for the initial decade of the NZ ETS. While decisions around subsequent action will need to be made, this approach would enable the business to manage risk through the establishment and settling-in phase of the NZ ETS and to ascertain the extent of alignment in the treatment of agriculture across international emission trading schemes.

In this case study, there was close alignment between the level of emissions calculated by applying the Climate Change Regulations emission factors and the

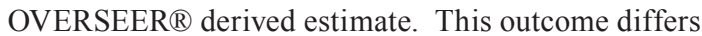
from data from other farms where the level of livestock emissions calculated by applying these emission factors can vary by $+/-40 \%$ from the OVERSEER $\AA$ derived estimate.

Aforestation can provide an opportunity to hedge against change in the cost of meeting liable livestock emissions, in addition to woodlot, land stabilisation and amenity benefits. Consideration of the minimum level of post-harvest carbon in the forest and the "safe to trade" quantity of NZUs is an important aspect of risk management.

\section{ACKNOWLEDGEMENTS}

Thanks to the McRae Trust Farm Trustees and the farmers who participated in the project.

This study was undertaken as part of a SFF Climate Change technology transfer series examining greenhouse gas and climate change implications with 10 case study groups. The programme was enabled through the support and funding of MAF, Beef + Lamb New Zealand, PGgRc, Deer Industry New Zealand, DairyNZ and AgResearch

\section{REFERENCES}

Climate Change (Agriculture Sector) Regulations 2010. http://www.legislation.govt.nz/regulation/ public/2010/0335/1atest/DLM3253001. html?search=ts_regulation_climate + change+agricult ure+sector_resel $\& \mathrm{p}=1 \& \mathrm{sr}=1$

Climate Change Response (Emissions Trading) Amendment Act 2008. http://www.legislation. govt.nz/act/public/2008/0085/latest/DLM1130932. html? search $=$ ts_act_Climate + Change + Response $+($ Emissions + Trading $)+$ Amendment + Act +2008 noresel\&p $=1 \& \mathrm{sr}=1$

MAF 2011. A guide to look-up tables for forestry in the emissions trading scheme. ISBN 978-0-478-38463-5.

McRae Trust August 2011. http://www.mcraetrust. co.nz/founders_vision.htm 
Ravensdown 2009. Ravensdown price list effective 26/8/2009. http://www.ravensdown.co.nz/Resources/ Publications/PriceList/Default.htm

West, G.; Poole B.; Molony, K. 2008 Impact of carbon trading on the economics and environmental benefits of tree planting options - Envirolink study on McRae Trust land, Wairoa, Hawke's Bay. For Hawke's Bay Regional Council 